Canadian Journal of Animal Science Revue canadienne de science animale

\title{
INFLUENCE OF GRAIN SOURCE AND DRIED CORN DISTILLERS GRAINS PLUS SOLUBLES OIL CONCENTRATION ON FINISHING CATTLE PERFORMANCE AND FEEDING BEHAVIOR
}

\begin{tabular}{|r|l|}
\hline Journal: & Canadian Journal of Animal Science \\
\hline Manuscript ID & CJAS-2016-0219.R1 \\
\hline Manuscript Type: & Article \\
\hline Date Submitted by the Author: & 18 -Jan-2017 \\
\hline Complete List of Authors: & $\begin{array}{l}\text { Rodenhuis, Mary } \\
\text { Keomanivong, Faithe; North Dakota State University, Animal Sciences } \\
\text { Gaspers, James } \\
\text { Gilbery, Trent } \\
\text { Underdahl, Sarah } \\
\text { Bauer, Marc; North Dakota State University, Animal Sciences } \\
\text { Anderson, Vern; North Dakota State University, Carrington Research } \\
\text { Center } \\
\text { Engel, Chanda } \\
\text { Swanson, Kendall ; North Dakota State University, Animal Sciences }\end{array}$ \\
\hline Keywords: & $\begin{array}{l}\text { distillers grains, finishing cattle, grain source, feeding behavior, growth } \\
\text { performance, oil concentration }\end{array}$ \\
\hline
\end{tabular}




\section{INFLUENCE OF GRAIN SOURCE AND DRIED CORN DISTILLERS GRAINS PLUS SOLUBLES OIL CONCENTRATION ON FINISHING CATTLE PERFORMANCE AND FEEDING BEHAVIOR}

M. A. Rodenhuis, F. E. Keomanivong, J. J. Gaspers, T. C. Gilbery, S. R. Underdahl, M. L. Bauer, V. L. Anderson, C. L. Engel. and K. C. Swanson

M. A. Rodenhuis, F. E. Keomanivong, J. J. Gaspers, T. C. Gilbery, S. R. Underdahl, M. L. Bauer, and K. C. Swanson: Department of Animal Sciences, North Dakota State University, Fargo, ND 58108-6050

V. L. Anderson and C. L. Engel: Carrington Research Extension Center, North Dakota State University, Carrington ND 58421

Corresponding author: Kendall Swanson (e-mail: kendall.swanson@ndsu.edu)

Abbreviations: ADF, acid detergent fibre; ADG, average daily gain; BW, body weight; $\mathrm{CP}$, crude protein; DDGS, dried corn distillers grains plus solubles; DM, dry matter; DMI, dry matter intake; G:F, gain:feed; LMA, longissimus muscle area; KPH, kidney, pelvic, and heart fat; NDF, neutral detergent fibre. 
ABSTRACT: Eighty-one steers ( $428 \pm 3.5 \mathrm{~kg}$ of BW) were used to determine the effect of grain type (corn vs barley) and oil concentration of dried corn distillers grains plus solubles (DDGS; moderate $=7.9 \%$ vs low $=4.5 \%$ ether extract) on growth performance, feeding behavior, and carcass characteristics. Intake and feeding behavior traits were calculated from data generated via the Insentec feeding system. Steers were slaughtered with an average BW of $668 \pm 4.4 \mathrm{~kg}$. Final BW and ADG were not affected by grain type or DDGS oil concentration. Dry matter intake decreased $(P=0.002)$ and $\mathrm{G}: \mathrm{F}$ increased $(P=0.01)$ in steers fed diets containing barley. Daily visits to the feeder decreased $(P=0.05)$ but time eating per visit increased $(P=0.03)$ in steers fed diets containing barley than corn. Plasma urea $\mathrm{N}$ concentration was greater $(P \leq 0.05)$ in steers fed diets containing barley than corn and in steers fed diets containing low-oil DDGS than moderate-oil ddgs diets. There was no effect of treatment on carcass characteristics. These data indicate steers fed diets containing barley had improved G:F and that including low-oil vs. moderate-oil DDGS in a finishing diet does not influence growth performance, feeding behavior, or carcass measurements.

Key words: distillers grains, finishing cattle, grain source, feeding behavior, growth performance, oil concentration 


\section{INTRODUCTION}

Feed costs represent a large proportion of total costs of beef production. Utilizing different grain types can influence feed efficiency which is important for optimizing cattle performance (Owens et al. 1997). Dried corn distillers grains plus solubles (DDGS) is a valuable feed product utilized in finishing diets (Klopfenstein et al. 2008). Including corn DDGS in a barley-based diet has been shown to result in a linear increase in DMI and ADG with increasing inclusion in the diet (Anderson et al. 2011) and optimal inclusion may differ depending on grain source (Klopfenstein et al. 2008).

The ethanol industry is evolving and changing their production practices. This has resulted in changes in the nutrient composition, such as decreased oil concentration, of the final coproduct available as a feedstuff. Decreasing fat in the diet has been shown to decrease ADG in finishing steers (Zinn 1989). However, increasing oil concentration in the diet can also have a negative effect on digestibility of non-lipid energy sources (Jenkins 1993) which could be detrimental. Therefore, research is needed to determine what effect DDGS oil concentration has on finishing cattle performance, feeding behavior, and carcass quality when commonly fed feed grains are fed. We hypothesize that feeding corn and moderate-oil DDGS will improve growth performance and feeding behavior in finishing cattle. Our objectives were to determine the effects of grain source (corn vs. barley), DDGS oil concentration (4.5 vs. $7.9 \%$ of DM), and the interaction of grain type and DDGS oil concentration on finishing performance, feeding behavior, and carcass quality.

\section{MATERIALS AND METHODS}

All procedures with animals were approved by the North Dakota State University (NDSU) Animal Care and Use Committee. 


\section{Animals, Experimental Design, and Dietary Treatments}

Eighty-one steers $(428 \pm 3.5 \mathrm{~kg}$ of BW) predominately of Angus, Simmental, and Shorthorn breeding were used in a $2 \times 2$ factorial arrangement of treatments (grain type [dryrolled corn vs dry-rolled barley] and DDGS oil concentration [low oil, $4.5 \%$ ether extract vs. moderate oil, 7.9\% ether extract]; Table 1). The DDGS were obtained from two different ethanol plants because each plant only produced DDGS with one oil concentration and would be options for producers to use in the northern Great Planes. The steers were sorted by BW into 3 pens (light, medium, and heavy pens; $n=27$ per pen) and housed at the NDSU Beef Cattle Research Complex. Within each pen, steers were assigned randomly to 1 of 4 experimental treatment diets ( $n=6$ or 7 steers per treatment within pen; $n=20$ or 21 per treatment): 1) corn with moderate-oil DDGS, 2) corn with low-oil DDGS, 3) barley with moderate-oil DDGS, and 4) barley with lowoil DDGS (Table 2). Diets were formulated to meet or exceed recommendations for dietary intake protein, metabolizable protein, vitamins and minerals for a $410 \mathrm{~kg}$ finishing steer gaining $1.6 \mathrm{~kg} / \mathrm{d}$ (NRC 1996). Diets were offered for ad libitum intake. Steers were adapted to experimental diets by transitioning from a $60 \%$ concentrate to the final diet over a 21 -d period. Before the initiation of the experiment, steers were fed a $50 \%$ concentrate diet with corn as the grain source for 3 weeks to adapt to the feeding system.

\section{Body Weight and Feed Intake Measurements}

Steers were weighed before feed delivery for 2 consecutive days at the beginning and ending of the feeding period and every $28 \mathrm{~d}$ throughout the feeding period. Average daily gain was calculated by regressing BW on day of the experiment.

Radio frequency ID tags were placed in the right ear before the experiment. Each pen contained 8 electronic feeding stations (Hokofarm Group, B. V., Marknesse, The Netherlands) as 
described by Mader et al. (2009) and Islas et al (2013) allowing for offering specific dietary treatments and monitoring individual feed intake and feeding behavior characteristics. Each experimental diet was provided in 2 feeders per pen. Total DMI and feeding behavior traits were summarized (Montanholi et al. 2010; Swanson et al. 2014) as follows; events (number of bunk visits and meals daily), eating time (min; per visit, per meal, and per day) and feed intake (g; per visit, per meal, and per minute) and these data were summarized as the average of each individual steer starting on $\mathrm{d} 1$ of the experiment. A visit was defined as each time the Insentec system detected a steer at a bunk. A meal was defined as eating periods that might include short breaks separated by intervals no longer than 7 min (Forbes 1995; Montanholi et al. 2010).

\section{Feed Analysis}

Diet samples were collected weekly. Weekly samples were analyzed (Table 3) for DM by drying in a $55^{\circ} \mathrm{C}$ oven and ground to pass a $1-\mathrm{mm}$ screen. Weekly samples were analyzed for DM, ash, N (Kjehldahl method), ether extract, Ca, and P by standard procedures (AOAC 1990) and for NDF (assayed with heat stable amylase and sodium sulfite and expressed inclusive of residual ash) and ADF (expressed inclusive of residual ash) concentration by the method of Robertson and Van Soest (1981) using a fibre analyzer (Ankom Technology Corp., Fairport, NY). Percent CP was calculated by multiplying N concentration $\times 6.25$. Samples also were analyzed for starch (Herrera-Saldana and Huber 1989).

Processed corn and barley samples were analyzed for particle size following the procedure of ASAE (1993) with the following modifications: a Tyler Ro-Tap sieve shaker (W. S. Tyler, Mentor, OH) was substituted for the Tyler RX86 sieve shaker. To compensate for differences in sieve shakers, the wing nut supports were raised approximately $2.5 \mathrm{~cm}$ from the top of the sieves, allowing the sieves to rock back and forth. Thirteen sieves were used along 
with a bottom pan. The sieve sizes ranged from 3,360 to $53 \mu \mathrm{m}$. Particle size was calculated as the geometric mean diameter using the equations of Baker and Herrman (2002). Particle size $(\mathrm{mean} \pm \mathrm{SEM}$ ) for corn and barley was $2.46 \pm 0.151 \mathrm{~mm}$ and $2.95 \pm 0.136$, respectively.

\section{Carcass Characteristics}

Steers were marketed in 2 groups. Group one (heaviest steers) was fed for $119 \mathrm{~d}$ ( $\mathrm{n}=40$; $\mathrm{n}=10$ per treatment) and group two was fed for $155 \mathrm{~d}(\mathrm{n}=41 ; \mathrm{n}=10$ per treatment except $\mathrm{n}=$ 11 for corn with low-oil DDGS) before transport to the abattoir. Hot carcass weight was measured on the day of slaughter and carcass measurements were measured following a 24-h chill. Measurements collected were marbling, subcutaneous fat thickness at the $12^{\text {th }}$ rib, longissimus muscle area (LMA), and kidney, pelvic, and heart (KPH) fat percentage.

\section{Blood Collection, Plasma Urea-N Analysis, and Plasma Glucose Analysis}

Blood samples were collected by jugular venipuncture into vacuum tubes containing sodium heparin (Becton Dickinson, Rutherford, NJ) on d 28, 56, 84 and 112 before feeding on the same days as BW measurements. Plasma was isolated by centrifugation (Sorvall ST16R; Thermo Fisher Scientific, Waltham, MA) at 3,000 x g for $20 \mathrm{~min}$ at $4^{\circ} \mathrm{C}$ and stored at $-20^{\circ} \mathrm{C}$ until analysis. Plasma Urea-N was determined using the urease/Berthelot procedure (Chaney and Marbach 1962; Fawcett and Scott 1960). Plasma glucose was analyzed using the hexokinase/gluxose-6-phosphate dehydrogenase method (Farrance 1987) using a kit from Thermo Scientific (Pittsburgh, PA) Analyses were conducted using a 96-well microplate reader (Synergy, HI Microplate Reader; BioTek Instruments, Winooski, VT).

\section{Statistical Analysis}

Data were analyzed as a completely randomized block (days on feed) design using the mixed procedure (SAS Inst. Inc., Cary, NC) with a $2 \times 2$ factorial arrangement of treatments. 
The model included the effects of block (days on feed), grain type (corn vs. barley), DDGS oil concentration (low vs. moderate), and grain type $\times$ DDGS oil concentration interaction. Plasma urea-N and glucose were analyzed using repeated measures and included block (days on feed), day, grain type, DDGS oil concentration, grain type $\times$ DDGS oil concentration, grain type $\times$ day, and DDGS oil concentration $\mathrm{x}$ day in the model statement. Appropriate (minimize information criterion) covariance structures were used (Wang and Goonewardene, 2004). The diagonal covariance structure was used because it had the smallest Akaike information criterion, finite sample corrected Akaike information criterion, and Schwarz's Bayesian information criterion. Data were considered significant when $P \leq 0.05$ and a tendency was considered when $0.05<P \leq$ 0.10 .

\section{RESULTS}

Initial BW did not differ between steers fed diets differing in grain type or DDGS oil concentration (Table 4). Final BW and ADG did not differ between steers fed diets differing in grain type or DDGS oil concentration. Dry matter intake was lesser $(P=0.002)$ in steers fed diets containing barley than corn but did not differ between steers fed diets differing in DDGS oil concentration. Gain:feed was greater $(P=0.01)$ in steers fed diets containing barley than corn but did not differ between steers fed diets differing in DDGS oil concentration.

No differences were observed in hot carcass weight, marbling score, LMA, $12^{\text {th }}$ rib fat, or KPH fat between steers fed diets differing in grain type or DDGS oil concentration (Table 4).

There were lesser $(P=0.05)$ visits to the bunk per day in steers fed diets containing barley than corn but no differences were observed between steers fed diets differing in DDGS oil 
concentration (Table 5). There were no differences observed in meals per day between steers fed diets differing in grain type or DDGS oil concentration. Time eating per visit was greater $(P=$ $0.03)$ in steers fed diets containing barley than corn. There was a tendency $(P=0.06)$ for time eating per visit to be greater in steers fed diets containing low-oil DDGS than moderate-oil DDGS. Time eating per meal did not differ between steers fed diets differing in grain type or DDGS oil concentration. No differences were observed in eating rate per visit between steers fed diets differing in grain type. There was a tendency $(P=0.09)$ for eating rate per visit to be lesser for steers fed diets containing low-oil DDGS than moderate-oil DDGS. There was also a tendency $(P=0.06)$ for eating rate per meal to be lesser in steers fed diets containing barley than corn. No differences were observed in eating rate per meal between steers fed diets differing in DDGS oil concentration. There were no differences observed for eating rate per minute between steers fed diets differing in grain type or DDGS oil concentration. No differences were observed for the interaction of grain type and oil concentration of DDGS.

There was an effect of time $(P<0.001)$ for blood glucose concentrations as blood glucose was least on d 28 (data not shown). Plasma glucose concentration was not influenced by grain type, DDGS oil concentration, the interaction of grain type and DDGS oil concentration, and the interaction of time with grain type and DDGS oil concentration (Table 6). There was an effect of time $(P<0.001)$ for plasma urea $\mathrm{N}$ concentrations $(\mathrm{mg} / \mathrm{dL})$ as plasma urea $\mathrm{N}$ was least on d 28 (data not shown). Plasma urea $\mathrm{N}$ concentration was greater $(P<0.001)$ in steers fed diets containing barley than corn (Table 6). Plasma urea $\mathrm{N}$ concentration was greater $(P=0.05)$ in steers fed diets containing DDGS with low oil concentration than moderate oil concentration. There was no effect of the interaction of grain type and oil concentration of DDGS, or the 
interaction of time with grain type and oil concentration of DDGS on plasma urea N concentrations.

\section{DISCUSSION}

Feed costs represent a large proportion of total costs of beef production. Utilizing different grain types, specifically barley and corn, can have an impact on efficiency and should be taken into consideration when formulating diets to optimize feed costs and growth performance in cattle. Changes in the nutrient composition of DDGS, such as decreased oil concentration, could potentially impact efficiency and, therefore it is important to determine the effects on performance in finishing cattle.

There are conflicting research results in regards to the effects on growth performance in finishing cattle when different grain types are fed. Some research suggests that G:F increases in cattle fed barley-based diets compared to corn-based diets (Mathison and Engstrom 1995; Milner et al., 1995, 1996; Boss and Bowman 1996; Beauchemin et al. 1997; Kincheloe et al., 2003). However, other research suggests G:F is improved or is not influenced when feeding corn-based diets vs barley-based diets (Hill and Utely, 1989: Owens, 1995; Nelson et al., 2000). These differences could be because of a number of variables such as: diet composition, geographic region, grain variety, cattle genetics, etc. It appears that the decreased DMI was the main factor causing improved efficiency in the current study. Dry matter intake can be affected by roughage source and level in the diet (Galyean and Defoor 2002), grain processing (Owens et al. 1997), and several other factors, and therefore differences in diet composition, other than the grain, could affect how DMI and growth performance are influenced by grain type. Our results are in agreement with the data in the literature suggesting that feeding finishing cattle diets containing barley improves G:F as compared to finishing cattle fed diets containing corn. Interestingly, 
ADG over the first $28 \mathrm{~d}$ was lesser $(\mathrm{P}=0.002$; data not shown $)$ in steers fed diets containing barley than corn. This may be because the starch in barley has a faster degradation rate than corn (Nocek and Tamminga 1991) which may result in greater incidence of ruminal acidosis during adaptation. This negative effect on ADG during the adaptation period could potentially be reduced by increasing the time of the dietary adaptation period to the high-grain diet for cattle fed barley-based diets. However, research has also shown improved ADG in steers fed barleybased diets than corn- or oat-based diets over the first 56 days on feed (Zalinko et al. 2009). It is not clear as to the reasons for discrepancies between studies, but it could be because of a number of other factors including cattle age, genetics, other dietary ingredients, environment, etc.

Anderson et al. (2011) examined the influence of increasing DDGS inclusion from 0\% DDGS to $36 \%$ DDGS in barley-based growing and finishing diets. In the growing diet, G:F was greater in steers fed diets containing DDGS than steers fed diets without DDGS. This was mainly because of an increase in ADG with steers fed diets containing DDGS. In the finishing diet there was a linear increase in ADG for increasing DDGS inclusion in the diet. These results indicate that including DDGS in the diet appeared to increase growth rate in finishing cattle. Another study by Depenbusch et al. (2009) showed similar results for flaked corn-based diets where increasing DDGS in finishing diets (0\% DDGS to 75\% DDGS) resulted in increases in final BW and ADG. Bremer et al. (2015a) studied the effect of increasing distillers products with a reduced oil concentration. Their results indicated there was an increase in ADG with increasing reduced-oil MDGS (7.2\% oil) similar to normal-oil MDGS. Similar results were found when analyzing a reduced oil concentration (7.9\% oil) wet distillers grains plus solubles (WDGS) compared with a normal WDGS (11.3\% oil). Our research showed similar results when comparing $4.5 \%$ vs $7.9 \%$ oil DDGS than those of Bremer et al. (2015b) as there were no 
differences in growth performance or carcass quality. However, it should be pointed out that NDF and ADF concentrations were greater and starch concentrations lesser in the moderate-oil compared to the low-oil ddgs which could potentially result in a less digestible non-oil component of the ddgs in the moderate-oil ddgs.

There is little known about how feeding different grain type or decreasing the oil concentration of DDGS affects feeding behavior. Montanholi et al. (2010) reported that more efficient calves (lower residual feed intake) had slower eating rates, spent less time at the feeder per day, and ate smaller meals. Research from our laboratory has suggested that in highconcentrate finishing diets, increasing the degree of dry-roll processing of corn increased the number of meals per day and total time eating per day and decreased eating rate per minute (Swanson et al. 2014). This potentially could have been an adaptation of the cattle to attempt to mitigate ruminal acidosis by decreasing the rate of feed consumption and consuming more meals per $\mathrm{d}$. Because of the faster ruminal degradation rate of barley than corn (Nocek and Tamminga 1991), it might be expected for steers fed barley to attempt to mitigate ruminal acidosis by altering feeding behavior. Interestingly, in the current experiment, grain source did not impact number of meals per $\mathrm{d}$, total time eating per $\mathrm{d}$, and eating rate per minute. However, number of visits per day decreased and eating time per visit increased in steers fed diets containing barley than steers fed diets containing corn which could suggest that steers fed diets containing barley generally were less active and potentially spent more time resting and ruminating per day which could be associated with improved efficiency. Steers fed diets containing moderate-oil DDGS tended to spend less time at the bunk per visit than steers fed diets containing low-oil DDGS. This might suggest that increased oil concentration could result in short-term decreased palatability. However, oil concentration of DDGS did not seem to have an effect on growth 
performance. Interestingly, plasma urea $\mathrm{N}$ was greater in steers fed low-oil DDGS than moderate DDGS suggesting potential decreased ruminal protein degradation (Jenkins 1993) resulting in differences in ruminal ammonia absorption and thus urea production. However, these differences in plasma urea $\mathrm{N}$ concentration were not associated with differences in growth performance.

In conclusion, utilizing barley, in comparison to corn, in finishing cattle diets decreased DMI, increased G:F, and altered feeding behavior in cattle consuming a $90 \%$ concentrate diet without affecting carcass characteristics. Utilizing a lower-oil concentration DDGS did not impact growth performance, or carcass characteristics, and there were no interactions with either barley or corn, in the finishing diets. There was a tendency for oil concentration of DDGS to alter feeding behavior (time per visit). However, this did not seem to be associated with differences in growth performance. These data suggest that utilizing DDGS with a lower oil concentration in finishing diets does not negatively affect growth performance or carcass quality of finishing cattle fed barley- or corn-based diets.

\section{Acknowledgements}

The authors wish to thank student employees at the NDSU Beef Cattle Research Complex for assistance with feeding and caring for cattle and the employees of the NDSU Nutrition Laboratory for feed analysis. The authors wish to thank the North Dakota Corn Utilization Council for partial funding of the project.

\section{REFERENCES}

Anderson, V.L., Ilse, B.R., and Wiederholt, R. 2011. Effects of increasing levels of distillers grains in barley based diets on growing and finishing performance, carcass traits, and nutrients in manure. Prof. Anim. Sci. 27: 547-552. 
Association of Official Analytical Chemists (AOAC). 1990. Official methods of analysis. $15^{\text {th }}$ ed. AOAC, Arlington, VA.

Baker, S., and Herrman, T. 2002. Evaluating particle size. MF-2051. Kansas State University. Beauchemin, K.A., Jones, S.D.M., Rode, L.M., and Sewalt, V.J.H. 1997. Effects of fibrolytic enzymes in corn or barley diets on performance and carcass characteristics of finishing cattle. Can. J. Anim. Sci. 77: 645-653.

Boss, D.L., and Bowman, J.G.P. 1996. Barley varieties for finishing steers: I. Finishing performance, in vivo diet digestion, and carcass characteristics. J. Anim. Sci. 74: 19671972.

Bremer, M.L., Bittner, C.J., Burken, D.B., Erickson, G.E., and MacDonald, J.C. 2015a. Response to increasing concentrations of de-oiled modified distillers grains plus solubles in beef finishing diets. Nebraska Beef Report. Pages 74-76.

Bremer, M.L., Harris, M.E., Hansen J.A., Jenkins, K.H., Luebbe, M.K, and Erickson, G.E. 2015b. Feeding value of de-oiled wet distillers grains plus solubles relative to normal when fed with either dry-rolled corn or steam-flaked corn in beef finishing diets. Nebraska Beef Report. Pages 77-79.

Chaney, A.L., and Marbach, E.P. 1962. Modified reagents for determination of urea and ammonia. Clin. Chem. 8: 130-132.

Depenbusch, B. E., Coleman, C.M., Higgins, J.J., Drouillard. J.S. 2009. Effects of increasing levels of dried corn distillers grains with solubles on growth performance, carcass characteristics, and mean quality of yearling heifers. J. Anim. Sci. 87: 2653-2663.

Fawcett, J. K., and Scott, J. E. 1960. A rapid and precise method for the determination of urea. J. Clin Pathol. 13: 156-159.

Forbes, J.M. 1995. Feeding behavior. Pages 11-37 in: J. M. Forbes, ed, Voluntary food intake and diet selection in farm animals. CAB International, Wallingford, UK.

Galyean, M.L., and Defoor, P.J. 2002. Effects of roughage source and level on intake by finishing cattle. J. Anim. Sci. 81(E. Suppl. 2): E8-E16.

Herrera-Saldana, R., and Huber, J.T. 1989. Influence of varying protein and starch degradabilities on performance of lactating cows. J. Dairy Sci. 72: 1477-1483.

Hill, G. M., and Utley, P. R. 1989. Digestibility, protein metabolism and ruminal degradation of Beagle 82 triticale and Kline barley fed in corn-based cattle diets. J. Anim. Sci. 67: 17931804.

Islas, A., Gilbery, T.C., Goulart, R.S., Dahlen, C.R., Bauer, M.L., and K. C. Swanson, 2013. Influence of supplementation with corn dried distillers grains plus solubles to growing calves fed medium-quality hay on growth performance and feeding behavior. J. Anim. Sci. 92: 705-711.

Kincheloe, J.J., Bowman, J.G.P., Surber, L.M.M., Boss, D.L., Anderson, K.A., and Blake T.K. 2003. Effects of barley or corn on performance and digestibility in finishing diets. Proc. West. Sec. Am. Soc. Anim. Sci. 54: 363-365.

Klopfenstein, T.J., Erickson, G.E., and Bremer, V.R. 2008. Board-Invited Review: Use of distillers by-products in the beef cattle feeding industry. J. Anim. Sci. 86: 1223-1231.

Mader, C. J., Montanholi, Y.R., Wang, Y.J., Miller, S.P., Mandell, I.B., McBride, B.W., and Swanson, K.C. 2009. Relationships among measures of growth performance and efficiency with carcass traits, visceral organ mass, and pancreatic digestive enzymes in finishing cattle. J. Anim Sci. 87: 1548-1557. 
Mathison, G.W., and Engstrom, D.F. 1995. Ad libitum versus restricted feeding of barley- and corn based finishing diets. Can. J. Anim. Sci. 75:637-640.

Milner, T.J., Bowman, J.G.P, and Sowell, B.F. 1995. Effects of barley variety or corn on finishing performance and feeding behavior. Proc. West. Sec. Am. Soc. Anim. Sci. 46: 539-542.

Milner, T.J., Bowman, J.G.P., Surber, L.M.M., McGinley, S.D., Daniels, T.K., and Daniels, J.T. 1996. Finishing performance and carcass characteristics of beef steers fed corn or barley. Proc. West. Sec. Am. Soc. Anim. Sci. 46: 539-542.

Montanholi, Y. R., Swanson, K.C., Palme, R., Schnekel, F.S., McBride, B.W., Lu, D., and Miller, S.P. 2010. Assessing feed efficiency in beef steers through feeding behavior, infrared thermography and glucocorticoids. Animal 4: 692-701.

Nelson, M.L., Busboom, J.R., Cronrath, J.D., Falen, L., and Blankenbaker. A. 2000. Effects of graded levels of potato by-products in barley- and corn-based beef finishing diets. I. Finishing performance, carcass traits, meat composition, and appearance. J. Anim. Sci. 78: 1829-1836.

Nocek, J.E., and Tamminga,S. 1991. Site of digestion of starch in the gastrointestinal tract of dairy cows and its effect on milk yield and composition. J. Dairy. Sci. 74:3598-3629.

NRC. 1996. Nutrient Requirements of Beef Cattle. $7^{\text {th }}$ Ed. National Academy Press, ed. Washington, DC.

Owens, F., Secrist, D., and Gill, D. 1995. Impact of grain sources and grain processing on feed intake by and performance of finishing cattle. Proceedings Symposium Intake by Finishing Cattle. Oklahoma Agricultural Experiment Station. Report P-942. Pages 235256.

Owens, F.N., Secrist, D.S., Hill, W.J., and Gill, D.R. 1997. The effect of grain source and grain processing on performance of finishing cattle: a review. J. Anim. Sci. 75: 868-879.

Robertson, J. B., and, Van Soest, P.J. 1981. The detergent system of analysis and its application to human foods. Pages 123-158 in W. P. T. James and O. Theander, eds. The analysis of dietary fiber. Marcell Dekker, New York.

Swanson, K.C., Islas, A., Carlson, Z.E., Goulart, R.S., Gilbery, T.C., and Bauer, M.L. 2014. Influence of dry-rolled corn processing and increasing dried corn distillers grains plus solubles inclusion for finishing cattle on growth performance and feeding behavior. J. Anim. Sci. 92: 2531-2537.

Wang, Z., and Goonewardene, L.A. 2004. The use of MIXED models in the analysis of animal experiments with repeated measures data. Can. J. Anim. Sci. 84: 1-11.

Zalinko, G.R., Racz, V.J., Rossnagel, B.G., Christensen, D.A., and McKinnon, J.J. 2009. Performance and carcass characteristics of steers fed a low acid-detergent lignin hull, high-oil groat oat in growing and finishing diets. Can. J. Anim. Sci. 89: 521-530.

Zinn, R.A. 1989. Influence of level and source of dietary fat on its comparative feeding value in finishing diets for steers: finishing cattle growth and performance. J. Anim. Sci. 67: 1029-1037. 
Table 1. Analyzed nutrient concentration of dried corn distillers grains plus solubles (DM basis).

\begin{tabular}{lcc}
\hline Dietary Component, \% of DM & $\begin{array}{c}\text { Low-oil } \\
\text { DDGS }\end{array}$ & $\begin{array}{c}\text { Moderate- } \\
\text { oil DDGS }\end{array}$ \\
\hline Crude protein, \% of DM & 31.6 & 32.6 \\
Neutral detergent fiber, \% of DM & 34.8 & 46.1 \\
Acid detergent fiber, \% of DM & 10.9 & 14.2 \\
Ether extract, \% of DM & 4.5 & 7.9 \\
Calcium, \% of DM & 0.04 & 0.04 \\
Phosphorus, \% of DM & 1.04 & 0.93 \\
Starch, \% of DM & 8.87 & 3.57 \\
\hline
\end{tabular}

Table 2. Dietary composition.

\begin{tabular}{lcccc}
\hline & \multicolumn{2}{c}{ Rolled Corn } & \multicolumn{2}{c}{ Rolled Barley } \\
\hline $\begin{array}{l}\text { Dietary Component, \% of } \\
\text { DM }\end{array}$ & $\begin{array}{c}\text { Low-oil } \\
\text { DDGS }\end{array}$ & $\begin{array}{c}\text { Moderate- } \\
\text { oil DDGS }\end{array}$ & $\begin{array}{c}\text { Low-oil } \\
\text { DDGS }\end{array}$ & $\begin{array}{c}\text { Moderate- } \\
\text { oil DDGS }\end{array}$ \\
\hline Dry-rolled corn $^{\mathrm{a}}$ & 50 & 50 & - & - \\
Dry-rolled barley $^{\mathrm{b}}$ & - & - & 50 & 50 \\
Dried corn distillers grains & & & & \\
plus solubles $_{\text {Corn silage }}$ & 25 & 25 & 25 & 25 \\
Limestone & 20 & 20 & 20 & 20 \\
Urea $_{\text {Salt }}$ & 2 & 2 & 2 & 2 \\
Vitamin premix $^{\mathrm{c}}$ & 0.15 & 0.15 & - & - \\
Mineral premix $^{\mathrm{d}}$ & 0.05 & 0.05 & 0.05 & 0.05 \\
Rumensin $^{\mathrm{e}}$ & 0.01 & 0.01 & 0.01 & 0.01 \\
Tylan $^{\mathrm{f}}$ & 0.05 & 0.05 & 0.05 & 0.05 \\
Fine-ground corn & 0.02 & 0.02 & 0.02 & 0.02 \\
\hline
\end{tabular}

${ }^{\mathrm{a}} 2.46 \pm 0.1514 \mathrm{~mm}$.

$\mathrm{b}_{2.95} \pm 0.136 \mathrm{~mm}$.

${ }^{\mathrm{c}}$ Contained 48,510 kIIU/kg vitamin A and 4,630.5 kIU/kg vitamin D.

${ }^{\mathrm{d}}$ Contained 3.62\% Ca, 2.56\% Cu, 16\% Zn, 6.5\% Fe, 4.0\% Mn, $1.050 \mathrm{mg} / \mathrm{kg} \mathrm{I}$, and $250 \mathrm{mg} / \mathrm{kg}$ Co.

${ }^{\mathrm{e}}$ Contained $176.4 \mathrm{~g}$ monensin/kg premix.

${ }^{\mathrm{f}}$ Contained $88.2 \mathrm{~g}$ tylosin $/ \mathrm{kg}$ premix. 
Table 3. Analyzed nutrient concentration of diets (DM basis).

\begin{tabular}{lcccc}
\hline & \multicolumn{2}{c}{ Rolled Corn } & \multicolumn{2}{c}{ Rolled Barley } \\
\hline Dietary Component, \% of DM & $\begin{array}{c}\text { Low-oil } \\
\text { DDGS }\end{array}$ & $\begin{array}{c}\text { Moderate-oil } \\
\text { DDGS }\end{array}$ & $\begin{array}{c}\text { Low-oil } \\
\text { DDGS }\end{array}$ & $\begin{array}{c}\text { Moderate-oil } \\
\text { DDGS }\end{array}$ \\
\hline Crude protein & 13.7 & 14.0 & 14.8 & 14.8 \\
Neutral detergent fiber & 29.8 & 31.8 & 32.6 & 34.7 \\
Acid detergent fiber & 11.9 & 12.5 & 13.3 & 14.1 \\
Ether extract & 3.49 & 4.18 & 2.40 & 3.11 \\
Calcium & 1.09 & 1.16 & 1.15 & 1.07 \\
Phosphorus & 0.46 & 0.46 & 0.50 & 0.48 \\
Starch & 43.6 & 42.1 & 37.1 & 37.5 \\
\hline
\end{tabular}


Table 4. Effects of grain source and oil level of dried distillers grains plus solubles on growth performance and carcass characteristics in finishing cattle.

\begin{tabular}{|c|c|c|c|c|c|c|c|c|}
\hline \multirow[b]{3}{*}{ Item } & \multicolumn{4}{|c|}{ Treatment } & \multirow[b]{3}{*}{$\mathrm{SEM}^{\mathrm{a}}$} & \multirow[b]{3}{*}{ Grain } & \multirow[b]{3}{*}{ DDGS } & \multirow[b]{3}{*}{ Grain*DDGS } \\
\hline & \multicolumn{2}{|c|}{ Rolled Corn } & \multicolumn{2}{|c|}{ Rolled Barley } & & & & \\
\hline & $\begin{array}{l}\text { Low-oil } \\
\text { DDGS }\end{array}$ & $\begin{array}{l}\text { Moderate- } \\
\text { oil DDGS }\end{array}$ & $\begin{array}{l}\text { Low-oil } \\
\text { DDGS }\end{array}$ & $\begin{array}{l}\text { Moderate- } \\
\text { oil DDGS }\end{array}$ & & & & \\
\hline Initial weight, kg & 425 & 426 & 432 & 425 & 7.1 & 0.74 & 0.66 & 0.57 \\
\hline Final weight, kg & 664 & 672 & 671 & 663 & 8.8 & 0.89 & 0.94 & 0.34 \\
\hline $\begin{array}{l}\text { Average daily } \\
\text { gain, } \mathrm{kg} / \mathrm{d}\end{array}$ & 1.79 & 1.84 & 1.82 & 1.80 & 0.040 & 0.79 & 0.68 & 0.41 \\
\hline $\begin{array}{l}\text { Dry matter intake, } \\
\mathrm{kg} / \mathrm{d}\end{array}$ & 12.1 & 11.9 & 11.3 & 11.3 & 0.22 & 0.002 & 0.85 & 0.75 \\
\hline Gain:feed & 0.149 & 0.1514 & 0.161 & 0.159 & 0.0034 & 0.01 & 0.62 & 0.24 \\
\hline $\begin{array}{l}\text { Hot carcass } \\
\text { weight, kg }\end{array}$ & 410 & 412 & 407 & 407 & 6.3 & 0.52 & 0.82 & 0.85 \\
\hline Marbling score ${ }^{\mathrm{b}}$ & 508 & 477 & 475 & 483 & 26.8 & 0.62 & 0.67 & 0.46 \\
\hline Ribeye area, $\mathrm{cm}^{2}$ & 88.4 & 91.6 & 89.0 & 87.7 & 0.33 & 0.55 & 0.59 & 0.26 \\
\hline $12^{\text {th }}$ rib fat, $\mathrm{cm}$ & 1.37 & 1.27 & 1.28 & 1.34 & 0.042 & 0.96 & 0.86 & 0.45 \\
\hline $\begin{array}{l}\text { Kidney, pelvic, } \\
\text { and heart fat, } \%\end{array}$ & 1.84 & 1.82 & 1.83 & 1.79 & 0.042 & 0.56 & 0.53 & 0.84 \\
\hline
\end{tabular}

${ }^{\mathrm{a}}$ Standard error of the mean $(\mathrm{n}=20)$.

${ }^{\mathrm{b}} 400$ to $499=$ small, $500-599=$ modest. 
Table 5. Effects of grain source and oil level of dried distillers grains plus solubles on feeding behavior in finishing cattle.

\begin{tabular}{|c|c|c|c|c|c|c|c|c|}
\hline \multirow[b]{3}{*}{ Item } & \multicolumn{4}{|c|}{ Treatment } & \multirow[b]{3}{*}{$\mathrm{SEM}^{\mathrm{a}}$} & \multirow[b]{3}{*}{ Grain } & \multirow[b]{3}{*}{ DDGS } & \multirow[b]{3}{*}{ Grain*DDGS } \\
\hline & \multicolumn{2}{|c|}{ Rolled Corn } & \multicolumn{2}{|c|}{ Rolled Barley } & & & & \\
\hline & $\begin{array}{l}\text { Low-oil } \\
\text { DDGS }\end{array}$ & $\begin{array}{l}\text { Moderate- } \\
\text { oil DDGS }\end{array}$ & $\begin{array}{l}\text { Low-oil } \\
\text { DDGS }\end{array}$ & $\begin{array}{l}\text { Moderate- } \\
\text { oil DDGS }\end{array}$ & & & & \\
\hline \multicolumn{9}{|c|}{ Events, per day } \\
\hline Visits & 27.1 & 28.6 & 23.1 & 26.2 & 1.6 & 0.05 & 0.16 & 0.60 \\
\hline Meals & 7.35 & 7.62 & 7.61 & 7.55 & 0.257 & 0.71 & 0.68 & 0.53 \\
\hline \multicolumn{9}{|l|}{$\begin{array}{l}\text { Time eating, } \\
\text { minute }\end{array}$} \\
\hline Per visit & 3.46 & 3.18 & 4.21 & 3.55 & 0.248 & 0.03 & 0.06 & 0.44 \\
\hline Per meal & 12.67 & 11.30 & 11.68 & 11.88 & 0.561 & 0.71 & 0.29 & 0.17 \\
\hline \multicolumn{9}{|l|}{ Eating rate, $\mathrm{kg}$} \\
\hline Per visit & 0.465 & 0.451 & 0.547 & 0.454 & 0.0312 & 0.17 & 0.09 & 0.20 \\
\hline Per meal & 1.69 & 1.60 & 1.53 & 4.52 & 0.066 & 0.06 & 0.42 & 0.53 \\
\hline Per minute & 0.136 & 0.142 & 0.135 & 0.130 & 0.0047 & 0.17 & 0.95 & 0.25 \\
\hline
\end{tabular}

${ }^{\mathrm{a}}$ Standard error of the mean $(\mathrm{n}=20)$. 
Table 6. Effects of grain source and oil level of dried distillers grains plus solubles on feeding on plasma glucose and urea $\mathrm{N}$ concentration.

\begin{tabular}{|c|c|c|c|c|c|c|c|c|}
\hline \multirow[b]{3}{*}{ Item } & \multicolumn{4}{|c|}{ Treatment } & \multirow[b]{3}{*}{$\mathrm{SEM}^{\mathrm{a}}$} & \multirow[b]{3}{*}{ Grain } & \multirow[b]{3}{*}{ DDGS } & \multirow[b]{3}{*}{ Grain*DDGS } \\
\hline & \multicolumn{2}{|c|}{ Rolled Corn } & \multicolumn{2}{|c|}{ Rolled Barley } & & & & \\
\hline & $\begin{array}{l}\text { Low-oil } \\
\text { DDGS }\end{array}$ & $\begin{array}{l}\text { Moderate- } \\
\text { oil DDGS }\end{array}$ & $\begin{array}{l}\text { Low-oil } \\
\text { DDGS }\end{array}$ & $\begin{array}{l}\text { Moderate- } \\
\text { oil DDGS }\end{array}$ & & & & \\
\hline $\begin{array}{l}\text { Plasma glucose, } \\
\mathrm{mg} / \mathrm{dL}^{\mathrm{b}}\end{array}$ & 99.3 & 99.4 & 97.5 & 98.5 & 1.08 & 0.21 & 0.64 & 0.68 \\
\hline $\begin{array}{l}\text { Plasma urea } \mathrm{N}^{\mathrm{c}} \text {, } \\
\mathrm{mg} / \mathrm{dL}\end{array}$ & 16.5 & 16.2 & 19.6 & 18.6 & 0.32 & $<0.001$ & 0.05 & 0.21 \\
\hline
\end{tabular}

${ }^{\mathrm{a}}$ Standard error of the mean $(\mathrm{n}=20)$.

${ }^{b}$ Day $P=<0.003$, Day $\times$ Grain $P=0.95$, Day $\times$ DDGS $P=0.21$, Day $\times$ Grain $\times$ DDGS $P=0.71$.

${ }^{\mathrm{c}}$ Day $P=<0.001$, Day $\times$ Grain $P=0.44$, Day $\times$ DDGS $P=0.78$, Day $\times$ Grain $\times$ DDGS $P=0.88$. 